\title{
HUMAN NATURE BASED ON AL-QUR'AN AS THE BASIC OF EDUCATION DEVELOPMENT
}

\author{
Abdul Kodir \\ State Islamic University (UIN) Sunan Gunung Djati Bandung, Indonesia \\ Jl. A. H. Nasution No. 105, Bandung, West Java-Indonesia \\ Email: Dr.abdulkodir@gmail.com \\ Wawan Sonjaya \\ State Islamic Institute (IAI) Bunga Bangsa Cirebon, Indonesia \\ Jl. Widasari III Tuparev Cirebon West Java-Indonesia \\ Email: sonjaya.hwawan06@gmail.com
}

\begin{abstract}
This research focuses on perspective of human nature based on Al-Qur'an as the basic of education development. It used descriptive qualitative method of research as well as library research which aims at collecting data and information from various literatures available in the library such as books, magazines, scripts, notes, histories, and other documents. The results of this research are drawn into conclusion, among others: first, based on all terms refering to human meaning, it can be defined that human nature required in Al-Qur'an apparently leads to the term alinsân. On the other side, from human structure's perspective, Al-Qur'an describes human as a creature consisting of physical and spiritual elements. Meanwhile from his position and role, human nature based on Al-Qur'an is described as Allah's servant and Allah's khalifah on Earth. Second, there is a close relationship both directly and indirectly with education concept in Al-Qur'an. Third, the concept of human nature in Al-Qur'an which cannot be separated from its education concept, thus, has a basic implication toward all education aspects, especially, in vision, orientation and objective of education, curriculum, methodology of education and evaluation on education. Fourth, process of education development based on concept of human nature in Al-Qur'an including objective, curriculum, methodology, and evalution of education aspects, basically, is understood as efforts or ikhtiar to develop all human existences in the term of totality, structure, position, role and other their own potential values.
\end{abstract}

Keywords: Human Nature, Al-Qur'an, Education Development

\begin{abstract}
ABSTRAK
Penelitian ini bertolak dari kajian filosofis tentang hakikat manusia dalam Al-Qur'an sebagai dasar pengembangan pendidikan. Penelitian ini termasuk ke dalam jenis penelitian kualitatif deskriptif dan penelitian kepustakaan (library research). Penelitian kepustakaan bertujuan untuk. mengumpulkan data dan informasi dengan bantuan macam-macam materi yang terdapat di ruang kepustakaan, misalnya buku-buku, majalah, naskah-naskah, catatan, kisah sejarah, dokumen
\end{abstract}


dan lain-lain. Dari hasil penelitian ini dapat disimpulkan: Pertama, berdasarkan kajian terhadap semua term yang merujuk makna manusia, dapat diketahui bahwa hakikat manusia yang dikehendaki Al-Qur'an nampaknya mengarah pada term al-insân. Sementara dilihat dari sudut pandang struktur manusia, Al-Qur'an menggambarkan manusia sebagai makbluk yang terdiri dari unsur jasmani dan rohani. Adapun dilihat dari aspek kedudukan dan perannya, bakikat manusia dalam Al-Qur'an digambarkan memiliki kedudukan sebagai hamba Allah dan khalifah-Nya di muka bumi ini. Kedua, terdapat bubungan yang sangat erat baik. langsung maupun tidak langsung antara konsep hakikat manusia dengan konsep pendidikan dalam AlQur'an. Ketiga, gambaran konsep bakikat manusia dalam Al-Qur'an yang tidak dapat dipisabkan dari konsep pendidikannya tersebut selanjutnya memiliki implikasi dasar terhadap seluruh aspek pendidikan, terutama pada visi, orientasi dan tujuan pendidikan, muatan materi (kurikulum) dan metodologi pendidikan serta evaluasi pendidikan. Keempat, proses pengembangan pendidikan berdasarkan gambaran konsep bakikat manusia dalam Al-Qur'an yang meliputi aspek tujuan, kurikulum, metodologi dan evaluasi pendidikan, pada dasarnya dipahami sebagai sebuah ikhtiar untuk mengembangkan selurub wujud eksistensi manusia dalam arti nilai totalitas, struktur, kedudukan dan peran serta potensi-potensi yang dimilikinya.

Kata Kunci: Hakikat Manusia, Al-Qur'an, Pengembangan Pendidikan

\section{INTRODUCTION}

Human and how to treat like human are the basic study in the process of education. In fact, since education process is not only based on the process from, by, and for human but also based on his position, role and potential given by Allah, it is likely for human to learn continuously until he reaches happiness life in the world and after life.

Significance of human in the education process implies some cases which need to be formulated later. First, education needs to have basic philosophy thoughts which can contribute to holistic framework of human. What has been disccussed regarding human nature as it is revealed in chapter 2 of this disertation becomes an effort to search an intact humanity concept based on Al-Qur'an. Second, in all processes, education needs to put human as starting point and ultimate goal based on Al-Qur'an's perspective in formulating humanity philosophically.

Due to the importance of human position awarness on education process, it is no wonder if the early education activity always puts forward on human nature as its basic foundation. This can be understood since education activity cannot run smoothly if it does not have a strong basic foundation regarding human nature as education man. In addition, it can be concluded that all diversities both in education theory and practice are caused by different perspective in revealing those human nature realities.

Al-Qur'an as normative base has its own perspective for human nature which can be a basic foundation in formulating education theory and practice. In other words, Al-Qur'an's perspective can be regarded as a strong 
normative provision in developing education process that has been run so far. Such normative-theology reference has significant contribution especially in implementing reorientation, reformulaiton, and reorganization for education toward good human character building (insan kamil with akblaqul karimah).

Given the above considerations, it is interesting and reasonable to study human nature in Al-Qur'an's perspective associated with the development of education problem. This research aims to: 1) obtain human nature formula based on Al-Qur'an's perspective; 2) obtain an overview for a strong relationship between human nature concept and education concept in Al-Qur'an; and 3) obtain a formula for education development based on human nature in Al-Qur'an's perspective.

This research used qualitative approach meanwhile in the way of analysis, this research used descriptive method, instead of inferential. According to research setting, this research refers to library research which aims at collecting data and information with various materials available in the library such as books, magazines, scripts, notes, history, document and many more. Basically, literature or bibliography can be a basic and main tool for research practice analysis.

\section{DISCUSSION}

1. The Implication of The Term Basyar And al-insân toward Education

Process.

The use of the term al-insân in Al-Qur'an to describe human indicates that there is Al-Qur'an's will to form human totality which has perfect and comprehensive man including physical-pyschical, material-immaterial, biological-physiological, and spiritual elements. It is not as al-basyar which refers to human as a mature man both physical and biological that can do physical and concrete activities merely based on their nature condition.

The description of human totality as al-insân implies on compulsion to create a perfect education process which not only forms physical but also spritual elements. In other words, education process must lead to human formation in balance. Understandably, it is more related on education concept in Al-Qur'an referring to the meaning of education in term of tarbiyah (developing all potentials step by step), ta'lim (giving information to other human as mind creature) and ta'dîb (character/akblaqul building). Thus, the aim to be in balance human both physical and spiritual of al-insân can be achieved through potential development, knowledge searching and character building. 
2. The Implication of Human Structure toward Education Process

In structure, human consists of a perfect unsure construction both physical and spiritual. Besides physical element, human's spiritual construction also has a great concern in Al-Qur'an especially related to al-rûh, al-nafs, al-qalb, and al-'aql. This indicates that Al-Qur'an requires human quality perfection spritually which has purity al-rûh characteristics originating formerly from God's al-rûh ; has pure al-nafs (al-nafs al-zakiyyat) and peacefully (al-nafs al-muthma'innat); has a consistent al-qalb to the truth (no taqallub); and owns al-'aql that is able to understand and think of God's Almighty signs as the source of truth.

This human structural concept related to the education process definitely can bring an implication toward education's will. Therefore, education must attempt to build physical-spiritual human quality perfectly. The simplest thing can be applied through physical and spiritual education. Such education (riyâdhat al-jasmânî wa al-rûhânî) is directed to the form of physical strength, purity of al-rûh, purity and peacefulness of al-nafs, consistency of al-qalb, and the intelligence of al-'aql.

3. The Implication of Human's Position And Their Roles in Education Process

Human's position means its position and status as Allah's servant and khalifah on Earth. On the other hand, role and duty will be carried out based on human's position which is realized in the form of worship deeds meanwhile khalifah mission can be manifested by managing and creating a society that has good relationship with Allah, and its social life can be harmonous as well as maintaining, guiding, directing many things in order to reach their creation's purpose.

Their position and roles in education process can bring an implication to the compulsion of consciousness and intention straightening in any forms of activity including education activity. Human education activity as Allah's servant must be based on consciousness and intention of worship to Allah Swt. Whereas as khalifah, human is required to improve their potential continuously in developing science and technology in order to manage and create a society which has good relationship with Allah, other humans, and

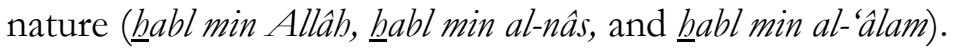

4. The Implication of Human Potential toward Education Process

Internal human potential which has characteristics fitrah and hanif certainly can bring an effect to the compulsion of education process which appreciates and develops its purity and righteousness (fitrah and hanif) that tend to taubid religion. In other words, education must lead to implantation taubid aspect in human self. 
The next potential is the unity of humans' physical and spiritual aspects as its perfection existence. This potential has implication to the education process that must balance the form of physical and spiritual aspects totally and perfectly. Perfect education lies on the form of sinergystic balance between physical and spiritual aspects.

To obtain physical and spritual balancing pattern, further, humans are given a freedom will to behave but their freedom must be understood as the realization of mandate (amanah) and responsibility. This implies to education process that must give freedoom to determine humans own destiny although this freedom must be placed in the context of their position and roles as Allah's servant and khalifah on Earth.

Internal potential owned by humans eventually ends on the use of mind. This brings an effect to education process in the broadness of potential mind's use for developing knowledge although the mind's superiority should not underestimate and ignore revelation (religion guidance).

Thus, to support the internal potential, Allah has released external potential in the form of religion guidance through revelation mediation. As a result, humans gain some information which is still unknown yet so far especially for the urgent things which bother their soul serenity or things which become requirement for their happiness. This potential has an implication to the education process as a means to dig and reveal religion messages. Therefore, by this revealation, it will be found the answer of happiness meaning both on Earth and After life.

Lastly, all human potentials both internal (fitrah, hanif, unity of soul and spirit, willingness potential, and mind potential) and external potential (religion guidance) are used to manage other potential, i.e., nature. This external natural potential is provided by God for humans as medium to reach life perfection in order to implement their position and role as Allah's servant and khalifah on Earth. Such natural potential has an implication to education process which prioritizes the development of knowledge that can be used as maximum as possible to explore natural resources broadly for the sake of all humans' needs.

\section{The Implication of Human Nature based on Al-Qur'an toward Education Process in the View of Education Process}

1. The Implication toward Vision, Orientation and Objective of Education

The implication toward vision, orientation, and objective of education can be viewed from humans' perspective, presupposes objective of education to the form of human totality as al-insân which has perfect and 
comprehensive appearance in physical, psychical, material-immaterial, biological-physiological, and spiritual elements. Moreover, it is not al-basyar which refers to human as a mature man both physical and biological that can do physical and concrete activities merely based on their nature condition.

On the other hand, based on human structure's perspective, the implication toward objective of education leads to manifestation on learners' balancing of physical and spiritual elements. This manifestation can be seen by the formation of personal learners who can optimize their physical and spiritual elements: al-qalb, al-nafs, al-rûh $\underline{\text {, and } a l ' a q l .}$

In addition, the implication humans' position and roles toward vision, orientation, and objective of education lies on the formation of awareness of learners who can realize their postion and role as Allah's servant and khalifah on Earth. Education's objective should direct learners to be aware of their position as Allah's servant in which all activities must be based on intention of worship to Allah. Whereas as khalifah, learners must be directed to be aware of improving their potential in managing and creating a society that has a good relationship with Allah, other human and nature.

Next, the implication of human potentials toward objective of education leads to the forming of personal learners who realizes their potentials both internal (fitrah, hanif, unity of soul and spirit, willingness potential, and mind potential) and external (religion guidance and natural potentials). In the view of fitrah and hanif, objective of education is directed toward an effort to optimize awareness of tendencious on religious and rightenousness values. In other words, objective of education from fitrah and hanifs perspective is directed to the achievement of humans who have good ethics and morality as well as social sensitivity.

Furthermore, based on the unity of body and soul potential, objective of education is directed to form of learners' awareness toward their totality as human perfectly who are able to balance physical and spiritual elements. In this case, it is not merely directed in the effort of growth and development of learners physiologically which emphasizes on the effort of material enrichment as it is shown excessively on skill aspect. In addition, education is not only led on the effort of mental spiritual enrichment aspect in order to pursue normative objective.

Objective of education based on physical and spiritual element leads to the forming of human's personality which works sistemically, simultanuously, and relationally developed through human integrity according to their fitrah and hanif potential. In other words, it is directed to achieve the growth of human personality in balance. Through this personality, it is expected to reach an ideal human prototype. This quality can be achieved by humans only if they can function their humanity as Allah's servant as well as khalifah. 
In human freedom potential's perspective, objective of education must be able to form personal learners who are free to express themselves and are not chained by any restriction forms which are not based on rational thought. As a matter of fact, this freedom will does not mean free as a bird since it is restricted on religion value and norm.

Then, implication toward education's objective in the view of mind potential owned by humans must lead to build personal learners who have high intelligence. So, it is expected to maximize mind potential in order to think all posibilities of knowledge development to create a better human life.

Another potential is religion guidance as external human potential. This potential has an implication toward objective of education to form learners' awarness of self imperfection if there is no God's religion guidance. Thus, objective of education is directed on deepening of importance of religious value in learners' life.

The last is natural potential which has an implication toward objective of education in the form of compulsion to build learners' personality who are able to optimize natural potential for the sake of human's needs broadly. This objective also leads learners to own knowledge and skills in utilizing any objects from nature for human needs as long as it does not harm human life itself.

From the above explanation, it can be drawn a conclusion that objective of education based on human term implies on the forming of human totallity as al-insân who has perfection and comprehension appearance in physical, psychical, material-immaterial, biological-physiological and spiritual elements as well as curriculum and methodology in education. Ideally, material and methodology in education contain contents which are postioning learners and optimizing their identity as the realization of al-insân as a perfect creature and it is not as al-basyar, i.e., creature in physical and biological meaning.

2. Implication toward Material Content (Curriculum) and Education Methodology

Basically, the concept of human nature related to education process can be implied not only on vision, orientation and objective of education but also on curriculum and education methodology as mentioned previously.

The nature of human structure implies on curriculum and methodology which appreciate learners' structure perfection through optimizing physical and spritual structures in material content and learning methodology. Therefore, content material and learning methodology which activate and develop learners' cognitive, affective and psychomotor domains become parts of human structure implication toward curriculum and 
education methodology. In education curriculum, education should insert learning materials that can train and educate physical and spiritual aspects in balance. Meanwhile, in education methodology, it is required to do inovation in learning methodology which can dig physical and spiritual elements in maximal and sustainable.

In addition, the implication of humans' position and role toward curriculum and education methodology lies on realization of content material and learning methodology that can affect learners' awarness in realizing their position and role as Allah's servant and khalifah on Earth. Material content and methodology should contain learners' awareness aspect toward their position as Allah's servant in which all activities must be based on intention of worship to Allah. Besides, those also contain an implementation effort of worship aspect both in the meaning of daily ritual and worship values in all aspects of life. Meanwhile in position and role as khalifah, material content and education methodology must contain leadership aspects theoretically and practically for learners' practice in improving their potential to manage and create a society that has good relationship with Allah, other human, and nature.

Next, the implication of human potential toward curriculum leads to materials which are possible for learners to realize and dig their own potentials optimally both internal (fitrah, hanif, unity of soul and spirit, willingness potential, and mind potential) and external (religion guidance and natural potentials). In order that content materials can be delivered well, it must be supported by education methodology which also attempts to dig and develop those potentials in learning process.

In fitrah and hanif potentials' perspective, material content contains learning material that is always related to learners' awarness of tendencious on religious and rightenousness values. It goes the same on education methodology that should attempt to use various approaches which lead to tendencious on religious and rightenousness values so that learners always maintain and develop their basic potential.

In further, since humans are admitted to have many basic potentials especially summed up in fitrah and hanif potentials, material content or education curriculum must cover all those potentials (unity of physical and spiritual, freedom will, mind potential, religion guidance, and nature). This material is a very strategic instrumental education aspect since it will directly give pattern (shibghat ) and direction (wijhat) for learners especially material that can maintain their personality integrity.

However, the implication of those potentials toward education curriculum does not mean to omit science field based on its available branch field. The science field is definitely needed because every learner has different 
background, interest, and intellectuality. Nevertheless, one thing that must be considered is how the science field will not bear negative effects to them. Such negative effects can be in the form of atomistic and dycotomic scientific pieces.

To obtain those things, it is required various kinds of educational method as an importance instrument in delivering materials. In particular, it will require an educational method which possibly occurs dialogic ambiance and can be a bridge for all science fields integrally.

\section{The Implication toward Education Evaluation}

Evaluation is a process of assessment on advance, growth, and development of learners for education objective. Evalution aims on identifying comprehension level of learners toward learning material, courage practice, and engage learners to review on the given materials previously. Evaluation target has not only purpose to evaluate learners but also to evaluate all education processes, i.e., how far that education process has run effectively to obtain education objective.

Finally, human nature concept in term, sturcture, position, role and potentials regarding to education process implies not only on vision, orientation, and objective education and its curriculum as explained above but also on the process of education evaluation.

The implication of human nature in term toward education evaluation can influence on evaluation process that must be able to measure and assess achievement level of learnes as al-insân. Meanwhile in structurally, evaluation process must be able to measure learners' potential in balancing their physical and spiritual aspects especially in managing al-qalb, al-nafs, al-rûhb, dan al-aql aspects.

Moreover, the implication on humans' position and role toward education evaluation can affect on evaluation pattern that can train learners' awareness level as Allah's servant and khalifah as well as can test and assess learners' potential level on applying worship values and khalifah values in society.

Finally, all of them can be realized if education evalution process can measure learners' success on maximazing all potentials both internal and external. Internally, learners are mapped their strength and weakness in all levels. Externally, education evaluation process can measure learners's success level in understanding all religion guidances as well as to measure how far learners can manage and utilize a small part of natural resources, on Earth which is awarded to them.

Through those descriptions, it can be formulated that human concept on Al-Qur'an, in fact, has implications toward education aspects particularly 
on vision, orientation, objective, material, methods, and evaluation of education. Thus, efforts on education development should be directed on those implication aspects. In referring to them, the efforts on education development are expected to have strong foundation ontologically due to human nature based on Al-Qur'an's perspective.

\section{Principles on the Basic of Education Development}

In education system, reconstruction and development can be conducted on two stages, i.e., macrocosmic (macro analysis) and microcosmic (micro analysis) of education world. This research focuses on the second stage, microcosmic approach. It means that in the effort of developing education system, it is conducted an analysis to one of philoshophical foundation units as its thought reference, i.e., its human nature's view based on Al-Qur'an's perspective. By conducting micro analysis, it is hoped to describe education basic values which must be developed according to AlQur'an's perspective concerning human nature. Furthermore, the development on that stage can improve synergity among other education units as well as it can be externalized into wider social frame.

The first thing to be concerned in the process of education development based on human nature in Al-Qur'an is the needs of formulation on basic principles as references in the process of education development. This principle has an important meaning in the process of education since it is not only based on formulation result of human nature and education in Al-Qur'an as described previously but also it can affect to aspects that become development object in education particularly in objective, curriculum, method, and evaluation of education.

Afterwards, according to analysis of human nature based on Al-Qur'an in the view of term, position, role, potential, education concept including tarbiyah, ta'lim dan ta'dîb, it can be formulated some basic principles for education development which consist of several dimensions: 1) the Nature of Human Creation; 2) Teology; 3) Morality; 4) Diversity Individual; 5) Social; 6) Professional; and 7) Time and Space Dimension.

\section{Education Development Aspects}

In microcosmic, education development is focused on aspects of objective, curriculum, method, and evaluation on education.

\section{The Development of Objective on Education}

In the process of education, objective formulation of education is comprehensive including all aspects, integreted in ideal personality pattern (Pribadi, 1971). Langgulung (1986: p. 8) stated that objective on education means humans' life objective themselves as it is stated implicitly on humans' position and role as Allah's servant and khalifah. In his opinion, education 
duty is to maintain humans' life in order to carry out their duty and position. Thus, objective on education is to form khalifah personality which has submission, obedience, and resignation attitude as Allah's servant.

On the other hand, Abdullah (2001, p. 193) proposed that objective on education must contain four aspects: 1) physical education; 2) spiritual and religion education; 3) Inttelectual education; and 4) social education (Abdullah, 1994, p. 8)

Similarly to this opinion above, Athiyah al-Ibrasyi in R $\underline{\underline{h}}$ al-Tarbiyyat wa al-Ta'lim, said that the core of objective on education is akblaq education. This objective emphasizes on mission of Prophet Muhammad Saw to accomplish precious akhlaq based on Allah's revelation. Nabi said that "In fact I was sent to build perfect character" (Al-Abrasyi, 1997, p. 6).

In addition, according to Imam Al-Ghazali, objective of education must be reflected in two sides, i.e.: 1) perfect Insan aims on getting closer to Allah Swt, dan (2) perfect Insan aims on getting happiness life on Earth and Hereafter. On the other hand, Ibnu Khaldun formulated objective of education based on QS. al-Qashshash [28]: 77 :

"through that which Allah has given you, the home of the Hereafter and yet do not forget your share of the world...".

According to the verse, Ibnu Khaldun has formulated two kinds of education's objective, they are: 1) ukhrowi orientation objective, to form a servant to do his obligation to Allah; 2) earthly orientation objective to form human who can face all aspects of life to be better and useful for others (Sulaiman, 1986, p. 24).

From those formulations, basically, objective of education focuses on three parts, those are: First, the formation of insan kamil (perfect human) which owns qur'ani or karimah akblaq (Rahardjo, 1989, p. 26). Second, the awareness of human's function as Allah's servant ('abdullab) and God's representative on Earth (khalifah fi al-ardh). Third, the creation of kaffah insan in religion, culture and knowledge dimension in which humans own physical structures al-ruh, al-nafs, al-qalb, and al-'aql.

Based on the exposition above, there are some principles containing in objective of education, among others: 1) Universal, the development of objective of education on this principle is to open, develop and educate human personality with all potentials; 2) Balancing and simplicity, the objective education on this principle means to realize a balance among learners' growth aspects and individual needs both recently and in the future.; 3) Clarity, this principle gives a clear and strict answer to soul and mind in solving a problem, challenge and crisis; 4) Realism and realization, These both principles attempt to reach objective through practical and realistic method based on fitrab; and 5) Dinamic Principle, objective of education 
on this principle is developed continuously and always renewed according to the change of era (As-Syaibani, 1979, p. 438-443).

\section{Curriculum Development}

In formally, curriculum as scientific study emerged in the beginning of 20th century. (Beuchamp, 1968, p. 26). Education curriculum began from particular field. For example in classic Islam education, religion studies dominated in curriculum for formal institution such as hadith, tafsir, fiqh, da'wah rhetoric, qalam study, philosophy, and hellenic studies. Nevertheless, by the development of cultural and social condition, curriculum content is getting wider. Thus, it requires general principles to be basic curriculum compilation.

First, Islamic spirit; meaning every thing related to curriculum including philosophy, objective, method, and other things must be based on religion spirit and Islam's akblaq. Second, universal; meaning objective and curriculum content must contain all aspects. (Ismail, 2001, p. 124). Third, balancing; objective and curriculum content must have a balance between world's concern and afterlife's concern by considering physical, al-rûb, al-nafs, al-qalb, al'aql development and other needs.

Fourth, it is based on psychological development related to talent, interest, skill, needs and condition of reality in which learners live and interact with others (As-Syaibany, 1978, p. 520-521). Fifth, concerning social environment; it means curriculum must accomodate society process for learners, in particular, their adaptation with their environment, their habitual and attitude, their thought and behaviour, their corporation and responsibility to environment. For the society, curriculum must be accomodative to develop and change the society to have a better life (Qurah, 1975, p. 47-49).

Furthermore, in its compilation, education curriculum must be based on an assumption in the nature of society, nature of human and nature of education itself. As-Syaibany has established four main foundations in developing education curriculum, i.e., religious, philosophical, psychological, and sosiological foundations (1979, p. 523-530).

Religious foundation means the compilation of education curriculum must be based on religious values in the holy Al-Qur'an and badith. Meanwhile, philosophical foundation provides direction and purpose of truth in value as a view of life that is believed from the truth. This foundation bears a framework formulation of education curriculum which consists of three basic dimensions of development: ontology, epistemology and axiology dimensions. On the other hand, psycological foundation considers learners' psyshical stage regarding physical development, maturity, physical talents, 
intellectual, language, emotion, social, individual needs and intention, interest and proficiency. This psycological foundation consists of students' and children psycology. Besides, sosiological faoundation gives a description that curriculum plays an important role in delivering and developing culture, individual socialization process, and society reconstruction.

Based on the explanation above, curriculum orientation is directed into: First, orientation on preservation of divinity and humanity values. Second, orientation on society trend to have high civilization. Third, orientation on human resource. Humans as biological creature have physical mecanism unsure that requires physical needs such as food and drink (QS. Al-Baqarah [3]:168), proper residence (QS. Al-Kahf [18]: 77), and other biological needs. (QS. Al-Kahf [18]: 82). Consequently, education curriculum must be directed to fulfil work needs with professional, producative, and creative skill and potentials which are able to use natural resources, human resources, and influencing situation resources. Thus, learners are prepared to be faithful Allah's servants who can do their duty as good Allah's khalifah. Nabi Muhammad Saw said that "those who want happiness in the world, then, they should be knowledgeable; those who want happiness afterlife, then, they should be knowledgeable; those who want both, then, they should be knowledgeable."

Fourth, orientation on learners. This orientation provides a compass for curriculum to fulfil learners's needs according to their talent, interest and potential. Fifth, orientation on the futuristic science and technology development. In fact, the development era is shown by the advance on science and technology with its products.

As explained above, curriculum should reflect a comprehension that all knowledges are originally Allah's creation meanwhile humans merely intepret thema (QS. Al-Kahf [18] :109) dan QS. Al-Isra' [17] : 85).

Therefore, the researcher offers several contents on education curriculum with three orientations presented through integrated approach, they are: First, curriculum content oriented on "divinity"; the formulation of curriculum content related to divinity deals with God's form, characteristics and deed in relation with humans and nature. This part encompasses taubid (aqidab), fiqh (syari'ah), akblaq, tasawwuf, Al-Qur'an and badith, and other knowledges.

Second, curriculum content oriented on "humanity". The formulation of this curriculum content concerns human personality as individual, social, cultural, and mind creature. This part includes politics, economics, culture, sosiology, antrophology, history, linguistic, arts, architect, philosophy, psychology, pedagogic, biology, medical, trading, communication, administration, mathematics, and many other sciences. 
Third, curriculum content oriented on "naturalness". The formulation of this curriculum content deals with universe phenomena. This covers physics, chemistry, agriculture, forestry, fishery, medicine, astronomy, outer space, geology, geophysics, botany, zoology, biogenetics, and other natural sciences. (Rosyadi, 2004, p. 276).

Those three parts of curriculum content are presented integratedly without any separation. For example, the topic is about God and his characters, thus, it will refer to God's relationship with humans and nature. In short, the curriculum content discusses the nature of God, human, and universe.

\section{Development of Education Method}

\section{Concept of Education Method}

In terminology, method is derived from two syllables, i.e., meta dan bodos. Meta means "through" and hodos means "path" or "way" (Arifin, 1993, p. 61). In other words, method can be a way to reach particular purpose. Besides, method is a means of finding, testing and composing data needed for developing its field of study (Barnadib, 1996, p. 85). In short, method, actually, is a road way to achieve its purpose (Langgulung, 1988, p. 183) which has meaning to find, test, and compile data needed for developing field of study or for sistemizing a thought. By this definition, method shows as a means to process and develop a idea so that it can produce a theory or finding. Through such method, any science can be developed.

Thus, method or way in Al-Qur'an is viewed from its object, function, character, effect and so on. This indicates that al-Qur'an put a high attention to method. In other words, al-Qur'an shows more signs to develop possible methods. Explicitly, Al-Qur'an does not show the meaning of education method since Al-Qur'an is not the science of method. A good understanding is required to find definition of method from other sources. A method might be suitable for particular lesson but it might not be appropriate for others.

In Arabic, word of method is expressed in many terms. Sometimes it is used in the words al-thariqah, manhaj, and al-wasilah. Al-thariqah means way, manhaj means system, and al-wasilah means meadium or mediator. In other words, the meaning of method in Arabic is closer to the word al-thariqah. Such word is found much in Al-Qur'an. Accroding to Muhammad Fuad Abd al-Baqy, al-thariqah is repeated nine times kali in Al-Qur'an. This word is sometimes connected with its object reference suc as hell, so it becomes way to hell (QS. al-Nisa: 169); sometimes it is related to its way character such as al-thariqah al-mustaqimah, meaning straight path (QS. Al-Ahqaf: 30); or it is related to way in particular place such as al-thariqah fil al-bahr meaning a dry path on the sea (QS. Thaha: 77); sometimes it refers to effect of obedience 
on the way (QS. Al-Jin: 16); and sometimes al-thariqah means solar system or sky (QS. Al-Mu'minun: 17).

Based on this terminology approach, method has a meaning as non physical way, i.e., way of ideas referring to take someone to achieve particular purpose. Nevertheless, in terminology, method has various meanings based on its context

\section{Function of Method}

Generally, function of education method is as the way provider or the best way for operasional implementation of education (Arifin, 1993, p. 61). In another context, method can be a medium to find, test, and compile data needed for developing field of study (Barnadib, 1996, p. 85). From these two approaches, in essence, method has function to deliver a purpose to object with a particular way based on the development of the object.

In Al-Qur'an, method is known as a medium to deliver someone to his creation purpose as khalifah on Earth by conducting some approaches in which human being owns physical and spiritual potentials used to deliver a lesson. Thus, there is a general principle in functioning a method, i.e., to a princple to deliver a lesson with fun, lively, enjoyable, and motivated so that it can be easily absorbed. Various methods are offered by many experts in education books to facilitate or find appropriate way based on learners' development in receiving the lesson.

In delivering lesson to learners as mentioned earlier, it is required a method with perception and philosophy in encountering humans based on their creation's unsures such as phyisical, spiritual and passion. Thus, education lessons served by Al-Qur'an always refer to the development of nafs (personal), spiritual, and phyisal aspects on humans themselves. There is a verse regarding God's skill and mighty (QS. Al-Anfal [8]: 7).

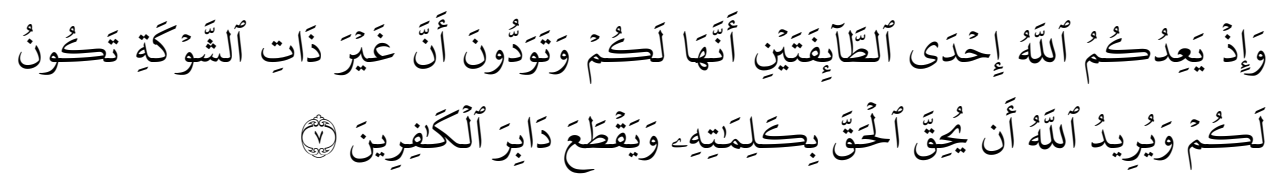

"and Allah was promising you one of the two parties that it should be yours. And youask for the one not armed to be yours. And Allah will that the truth should be realized with the words and that he should cut off the back (the continuation of progeny) of the disbelievers."

In short, it is clear that method is truly functioned in delivering education material. Based on Al-Qur'an, funtion of method must have a proper perception on human as a creature who can be educated through physical, spiritual and nafs aspects. As a result, there is a material related to 
cognitive, affective and psychomotor domains that require different methods.

\section{Principles of Education Method}

Method is an important aspect to transfer science from educator to learners so that there will be an internalization process and science ownership by learners. In Islamic education, education method becomes a huge concern. Al-Qur'an and badith are teaching sources containing directions and principles that can be interpreted into concepts of education method.

There are some principles that must be alerted in education method. First, compatability principle of learner psychology; method developed by educator must concern with learners' motivation, needs, interest and intention in learning process. In particular, educator should drive a hidden motivation, as well as keep and maintain the motivation so that learners are motivated to be more active to learn. In fostering and maintining this motivation, educator should combine between persuation and determination so that learners are not weak and do not own violence.

Second, maintainance of learning objective; Learning objective known by learners must be maintained and developed, in fact, guided so that they like the lesson. The main task of educator, in this case, is to assisst learners to set their learning objective and keep it during the teaching learning process.

Third, maintainance of maturity stage; maintainance of maturity stage in learning process is aimed at optimizing teaching efforts and enabling learners to take advantage from those given efforts. Therefore, teaching is delivered based on mind, observation stage and learners' comprehension. In addition, by maintenance of maturity stage, teaching learning process can occur lively and create a postive impression on learners

Fourth, practical praticipation; Emphasis on this principle is on action to embed and reinfornce learning objective. Change on education can be recognized through behaviour and implementation of method by observation and participation repeatedly (As-Syaibany, 1979, p. 595-604).

\section{Types of Education Method}

Given the above perspective, al-Qur'an offers various approaches and methods of education, particularly, in delivering education materials. Those methods are among others:

a. Modeling Method

In Al-Qur'an, the word model is projected in the word uswah following by an adjective such as hasanah meaning good. Thus, term of uswatun hasanah means good model. The word uswah is repeated in al-Qur'an for six times by sampeling the prophets such as Prophet Muhammad Saw., Prophet Ibrahim, and other clans who have a strong faith to Allah. In particular, this verse: In 
Prophet Mubammad himself you can find good example, is always mentioned as an evidence of modelling method in al-Qur'an.

Muhammad Quthb, for example, suggests that in Prophet Muhammad, Allah has compose a perfect Islam methodology, a form of life which is still alive and eternal along history until now (Muhammad Qutbh, 1984, p. 183). This method is considered to be important since the most important in religion aspect is akblaq which refers to affective domain and is showed in the form of behavior (behavioral).

To emphasize Rasulullah Saw model, al-Qur'an further explains akhlaq of Prophet Muhammad served in many verses in al-Qur'an. In Chapter alFath verse 29, for example, it is stated that character of Prophet Muhammad and his followers is strict to the heathen but full of affection to those who always ruku and sujud (shalat), looking for Allah's ridha. In another verse, it is explained that among Prophet Muhammad's duties are as witness, joyful news messanger, warning messanger, Allah's religion caller with Allah's will to be a lighter (QS. al-Ahzab:45-46). These duties as explained in history can be implemented well and successfully in which his influence is still felt and developed until now (Haikal, 1992, p. 448). This example shows that Prophet Muhammad in his duty can become a role model for his followers now and in the future.

Meanwhile, profile of Prophet Ibrahim is explained in the verse: Indeed on them (Ibrabim and his followers) there is a good role model for you (QS. alMumtahanah: 4). This role model of Prophet Muhammad is also imitated by Prophet Muhammad SAW. It is proved from Allah's revelation to Prophet Muhammad that contains an order to follow Prophet Ibrahim's command. Thus, in Islam ritual tradition, these two profiles (Ibrahim and Muhammad Saw.) become figures who can be reference for people recently and in the future. To recognize role model of Ibrahim, it can be enriched by reading his biography in al-Qur'an and other articles from realibly moslem scholars.

b. Story Methods

Story or tale is actually an eduction method that attracts someone's feeling. Islam realizes human nature to like tale which has big influence to feeling. Thus, Islam exploits tales to be one techniques of education (Qutb, 1984, p. 348). He tells various kinds of tale; factual history shows human life intended that it can be as like as the character described on the example; drama illustrates real fact but it can be applied anywhere and anytime.

Considering the aims and objectives of tale, al-Qur'an exposes the word tale or story for forty times as mentioned already. In Chapter alBaqarah verse 30 until 39, for example, it contains a tale about dialogue between Allah and the angels. Allah intends to reveal his khalifah on Earth 
from human type. The angels protested Allah's decision. After human had got teaching from Allah and showed his intelligence in front of the angels, finally, they admitted human as khalifah who was approved by Allah. This shows human's position who is more precious than other creatures since human has potential to be educated so that he can be a leader on Earth. Moreover, in this verse, it is also mentioned human's weakness, i.e., when Adam and Eve was sucessfully tempted by Evil until they were downgraded to Earth. However, both of them were repent immediately and begged for mercy from Allah. Message from this tale is that human has ability, strength and also weakness. Therefore, human must be aware of devil's temptation, human must live based on Allah's guidance.

This is one of examples of tale from al-Qur'an that can be used as one of ways to deliver message beyond the tale, i.e., faith and morality based on Allah's will. This is also an example of tale as an education method in alQur'an.

c. Advice Method

Al-Qur'an al-Karim also uses touching sentences to direct human to the intention's idea. This is known as nasihat. In addition, this advice includes role model of the advisor. This shows that between advice method and modelling method is complementary each other.

Advisor's target is to foster awarness to those who are advised that they become realized to follow rule or teaching imposed on them. This can be seen on what Luqmanul Hakim did to his son as described in Chapter Luqman verse 13 until 19 which encompasses several commands not to ally Allah, to do kindness to parents, be grateful to Allah, do prayers, tell others to do kindness, and not be arrogant (takabbur).

Similarly, another advise can be showed on al-Isra [17]: 22-38 which tells not to ally Allah, to do kindness to parents by praying for them, help other relatives, the poor, ibnu sabil, not to be spendthrift, miserly, or kill anyone without reason allowed in religion, not to use orphan's property, to keep on promise, to accomplish scale or dose, not to be a false witness, and not be arrogant.

Based on those advises, apparently, there is a repetition material on alQur'an. In that verse, a repitition advise occurs on prohibition to ally Allah, to do kindness to parents, and not to be arrogant. This repetition shows that the problem on advise is very important to be noticed based on the context.

Al-Qur'an explicitly uses advise as one of ways to deliver a teaching. Al-Qur'an tells about advisor, person who gets advice, advice object, advice situation, and advice background. Thus, as a method of teaching, advice is admitted its righteousness. 


\section{d. Habituation Method}

Another way used by al-Qur'an in providing education material is through habituation gradually. It includes change of negative habits. Habit is perceived as something special for human. It saves many human energies since it remains stickly and spontanously that is used in various activities and in many fields, in productivity, and other creativity. If habit is not given from Allah to humans, they will spend their life merely for walking, talking and other similar activities.

Al-Qur'an makes habit as one of techniques or methods of education. Then, it changes good characters into habit so that the soul can perform that habit with effortless, powerless, troubleless.

Al-Qur'an applies a gradual way in creating good habit, similarly in relieving bad habit in oneself. In line with this, there is Rasulullah's guidance that tells parents to have their children pray at seven years old, in further, to hit them at ten years old if their children do not pray yet. In attempting to create good habits, al-Qur'an takes two ways as follows:

First, through training and practicing. It begins with releasing mind from untrustworthiness principles and from following others to denounce blind people or taklid (QS. al-Zukhruf: 23). Then, by denouncing through statement that they just follow their assumptions, in fact, those assumptions are useless for righteousness (QS. al-Najm: 28). Furthermore, al-Qur'an commands that they conduct a research earlier to solve a problem before they believe, follow and accustom on it (QS. al-Isra: 36).

Second, through Allah's rules in this well organized universe. By study this, it not only recognizes nature's rules that bear teories in science but also emerges faith and pious to Allah as the creator of beautiful and tasteful universe. This second way will encourage habit to capture Allah's mighty signs and practice sensitivity.

Therefore, habituation used in al-Qur'an is not merely restricted on good habit manners but also on feeling and thought. In line with this, all of them must be appropriate with age level development of learner. Al-Ghazali, for example, suggests to use different method betweem children and adults. Al-Ghazali stated that: "Main obligation of educator is to teach something easy to understand for children since difficult issues can distract their thoughts so that they will runaway from science (Al-Abrasyi, 1974: 26). This sign can be found in al-Qur'an, i.e., giving burden by his capability.

Habitual process which eventually bears habituation is taken by alQur'an in order to establish the implementation its teaching materials. The habituation relates to passive and active aspects. However, it should be noticed that al-Qur'an proposes passive habituation only in the matters related to social and economic condition. It does not relate soulness with rule 
or ethics. Meanwhile active habituation which requires implementation is found completely (Syihab, 1992, p. 176).

e. Punishment and Rewards Method

In al-Qur'an, rule is known as arab which is repeated 373 times in alQur'an (Al-Baqy, 1987, p. 450-455). This huge amount shows that al-Qur'an gives much attention on this rule matter and ask humans to concern with it. Meanwhile the word reward in al-Qur'an is mentioned 105 times in the term ajrun (Al-Baqy, 1987, p. 12-14). This is also in a big number. In line with this, there are some verses: ... And if you turn back, as you turned back before, He will punish you with a painful punishment (QS. al-Fath: 16); They swear by Allah that they did not speak and certainly they did speak, the word of unbeliever, and disbelieved after their Islam and they did not fault except Allah and His Messenger enriched them out of His grace; therefore if they repent, it will be good for them. and if they turn back, Allah will chastise them with a painful chastisement in this world and the Hereafter and they shall not have in the land any guardian or a helper. (QS. al-Taubah: 74); And the thief, the male and female, cut off their hands as a recompense for what they have done as punishment from Allah and Allah is powerfull and all wise. (QS. al-Maidah: 38).

Those above verses not only admit the existence of punishment for humans' improvement but also show that not all punishments are applied to all humans, however, they only affect to those who break the rules. To let humans offend and let the offenders freely and disturb society are not humanity since they will lead to create more massive society ruin. Thus, the enforcement of punishment in education does not stop on its own punishment but on its purpose, i.e., the offenders become aware and repentance, and return to be a good person. If humans are already in good behavior, they will not be punished anymore.

Furthermore, some verses are related to rewards, such as: Their reward is forgiveness from their Lord and gardens beneath which rivers flow, to abide in them and excellent is the reward of the laborers (QS. Ali imran: 136)

To sum up, the existence of punishment and rewards are admitted in Islam and used in training humans through education activity. Punishment and rewards are applied to special guidance target. Punishment is given to those who offend the rule whereas those who obey the rule and do goodness will gain rewards or pabala.

f. Lecturing Method

Lecture or delivering a teaching material orally is admitted its existence and it has been practiced by Rasulullah Saw to invite humans to God's path. Recently, lecturing method is applied in lesson since it is the easiest, cheapest and toolless method. 


\section{g. Discussion Method}

Al-Quran also reveals discussion method to force definition and learners' knowledge attitude toward a problem (Arifin, 1993, p. 75). Allah's command is to take humans to the right path with good wisdom and man'izhah and to argue through discussion with the best way (QS. al-Nahl: 125); in al-Qur'an, moreover, discussion or al-mujadalah is repeated for 29 times. Discussion is admitted in Islamic education. However, as mentioned earlier, discussion must be based on good ways which must be formulated later so that it emerges discussion ethics, for example, not to monopolize discussion, to respect other opinions, maturity in thought and emotion, insightful, and other example.

There are still many other methods besides those explained above. Nevertheless, it is required to be considered in choosing method in education process based on both educators and learners psychology ability, situation on education process and education objective to be achieved.

\section{Development on Education Evaluation}

The last chain of component of education system is evaluation. It becomes a benchmark which is compatible with education objective both short and long term objectives. Short term objective is to guide humans to live safely on Earth meanwhile long term objective is to guide humans to after life prosperity.

Both objectives blend on attitude and behaviours which reflect precious akblaq. As a benchmark from precious akblaq, it can be reflected on humans' behaviours in daily life (Umar Said, 1996: p. 58).

\section{a. Definition of Evaluation}

Evaluation is an action process to determine anything related to education. Evaluation is an estimation process toward advance, growth, and development of learners for objective on education (Nurkancana, dkk., 1986: 1). Evaluation aims on recognizing learners' comprehension level towards lesson material, on training courage and on taking learners to review the given material. Besides, evaluation program aims on recognizing who among learners are clever and slow so that the slow learners can be treated specially to chase their backwardness. Evaluation target does not only evelaute learners but also educators, i.e., how far they do their duty to achive the objective of education.

Function of evaluation is to assisst learners so that they can change or develop their behavior consciously and help them how to reach satisfaction in proper manner. Besides, it assissts an educator to consider teaching method and his administration. 
Evaluation targets on education generally encompass four learner' ability, namely 1) Experience and attitude toward his personal relationship with God; 2) Experience and attitude between himself and society; 3) Experience and attitude between his life and environment; and 4) Perspective and his attitude to himself as Allah's servant, part of society and as Allah's khalifah (Muzayyin Arifin, 1994, p. 239).

\section{b. Evaluation Principles}

Parallel with this, the implementation of evaluation must concern the following principles :

\section{1) Continuity Principle}

Evaluation is not only carried out once in a year or per semester but it is conducted continuously from teaching learning process by concerning learners' condition until learners finish their study in that school. This continuity process is needed because someone's decision becomes valid and stable. Besides, it can result a benefit attitude. This principle is revealed in alAhqaf [46]:13-14 as follows:

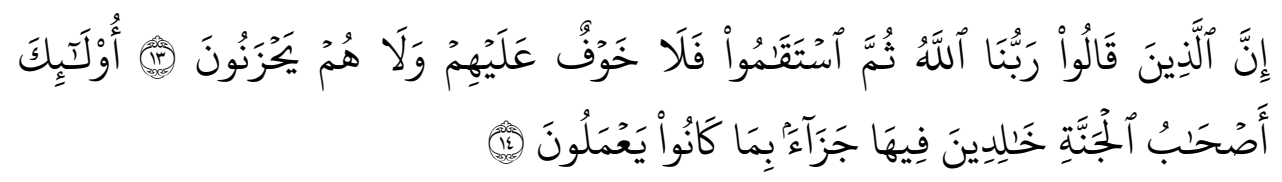

"Surely those who say, Our Lord is Allah, then they continue on right way, they shall have no fear nor shall they grieve. These are the dwellers of the garden, abiding therein: a reward for what they did."

2) Comprehensive Principle

Assessment conducted by educator becomes an integral part of teaching learning process. Evaluation is based on measuring comprehebsive result cosnsiting cognictive, affective, and psychomotor aspects (Rusyan, dkk., 1992, p. 211). This principle views all aspects from, personality, corporation, responsibility, memorizing sharpness, comprehension, sincerity, dilligence and many more. This is stated in Al-Zalzalah [99]: 7-8 as follows:

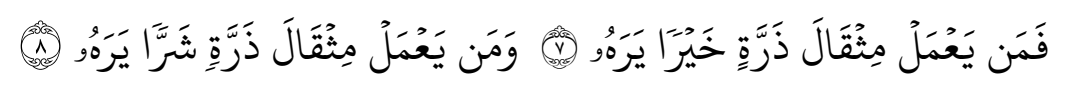

"7. So he who has done an atom's weight of good shall see it. 8. And he who has done an atom's weight of evil shall see it."

3) Objectivity Principle

In evaluating based on reality, it cannot be influenced by emotional and irrational matters (Rusyan, 1992, p. 211). In Islam, this assessment includes utterance (qawliyah), action (fi'liyah) and feeling (qalbiyab) which has tight 
relation to someone's faith condition (Sabiq, 1977, p. 17). Allah Swt. commands someone to be fair in evaluating something. He should avoid hatred that make evaluation less objective. This is proved in Al-Qura'an alMaidah [5]:8 as follows:

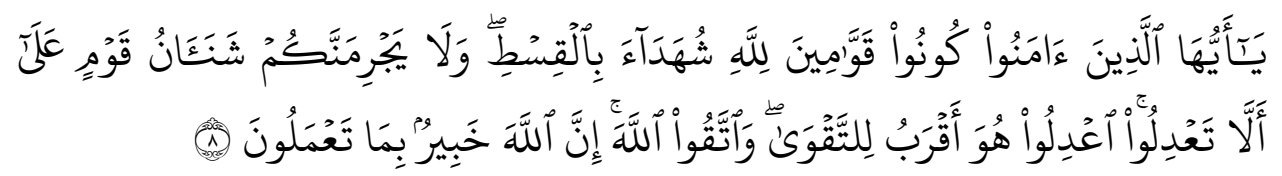

"O you who believe! Be upright for Allah, beares of wtiness with justice and let not batred of people incite you not to act equitably; act equitably, that is nearer to piety, and he careful of your duty to Allah; surely Allah is Aware of what you do."

Prophet Muhammad Saw. said once that "If Fatimah binti Mubammad steals, I will not fairly cut her hands off." It goes the same to Umar bin alKhaththab who whipped his son due to zina. This principle is applied if educator has common attitudes such as sidiq (honest), sincere, amanah, ta'awn, friendly and any good characters.

4) Fairness Principle

Fairness becomes an important principle that must be concerned by an educator in evaluation so that there is no imbalance, In the process of assessment, there are two kinds of assessment, i.e., norm referenced which is related to learning outcome and orientation referenced which refers to placement.

5) Honesty Principle

In the evaluation process, an educator must state something based on reality concretely without reducing and adding its truth essence. (Ahmad Amin, 1975: 68). Thus, he must assure to his assessment result. Indeed, he cannot assess something absurd (Abudin Nata, 1997, p. 141).

6) Openness

Assessment related to the final objective of learning process is done through openness assessment system. It means to use a clear, systematic, and organized system so that it will not emerge confusion for the learners (Rusyan, 1992, p. 2011).

Evaluation of education can be performed in two ways, namely self evaluation and other evaluation (learners). A moslem including a good and conscious learner, always evaluates himself regarding their strength that must be maintained and weakness that must be evaluated. Self evaluation is more contemplative reflection (QS. Al-Dzariyat [51]: 21).

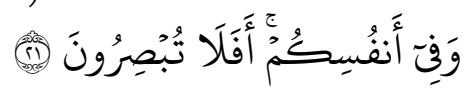


Umar bin Khattab once said that "Evaluate yourself before someone evaluates you." Thus, human is required to be aware of doing his action since Allah always evaluates him (QS. al-Baqarah [2]: 115),

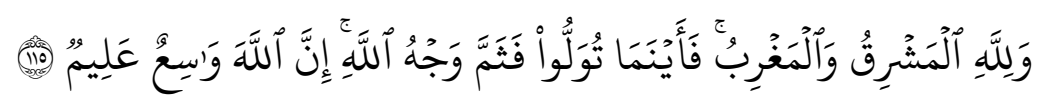

"And Allah's is the East and the West, therefore, whither you turn, thither is Allab's purpose; surely Allab is Amplegiving, Knowing."

Moreover, Allah sends two angel as supervisor, i.e., Roqib and Atid (QS. Qaf [50]: 18)

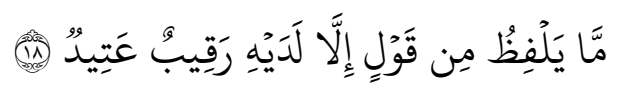

"He utters not a word but there is by him a watcher at hand."

On the other hand, evaluation for learners' activity must have an intention for amarma'ruf and nabimunkar which aims in improving other action and in implementing an education program. There is an assumption that in particular condition, someone sometimes can lose control so that he does unconscious action influencing by emotion and his subjectivity. In such contion, other people assess easily and evaluate his activity meanwhile the doer does not understand whether or not his action is correct or incorrect. Other evalution (educator) is more comparable meaning to assess learner clearly and incorrect answer will be corrected. It will not be ignored which make learners confused, dullness, and left behind.

To conclude, at the end of this paper, to develop education, it will need insightful openness and encourageness to solve education problems fundamentally and comprehensively related to: 1) calrity between goals and operational steps; 2) Empowering of vailable institution by recosntructing its system; 3) improvement, renewal and development of management system. Through these steps, it is expected that education can be acted more articulative in the future.

\section{CONCLUSION}

This research reveals a basic theoretical analysis of human nature as a blueprintof education practice. Besides, such research provides humanity insightful for theoretical and practical formulation of education. To make human to be more human thorugh education practice, this research recommends that education practice must be managed based on human nature as it is described in Al-Qur'an. Education process and practice must be directed to optimalize humans' potentials comprehensively, integrally, and integratedly. 
This research also recommends a clear and accurate formulation of objective of education based on human nature properly from his creator's perspective. The formulation of objective should be created on lesson or curriculum appropriately with the achieving objective. Besides, lesson or curriculum must be delivered with the proper learning method. To recognize the achievement of objective, it is required an accurate evaluation based on target evaluation.

\section{BIBLIOGRAPHY}

Rusyan, A. Tabrani, dkk., (1992). Pendekatan dalam Proses Belajar Mengajar, Bandung: Remaja Rosdakarya.

Muhaimin., (1993). Konsep Pendidikan Islam: Telaah Komponen dasar Kurikulum, Solo: Ramadhani.

Abdullah., (1994). Abdurrahman Shalih, Landasan dan Tujuan Pendidikan Islam menurut Al-Qur'an serta Implementasinya, Bandung: CV. Diponegoro,

Junaidi, Mahfud., (2001). "Konsep Tujuan Pendidikan dalam Al-Qur'an", dalam Ismail SM dkk. (ed.), Paradigma Pendidikan Islam, Yogyakarta: Pustaka Pelajar.

Nata, Abuddin., (1997). Filsafat Pendidikan Islam, Jakarta: Logos wacana Ilmu.

Amin, Ahmad., (1975). Ilmu Akblak, terj. Farid Mu'arif, Jakarta: Bulan Bintang.

Sulaiman, Fathiyah Hasan., (1986). Pendidikan Menurut al-Ghazali, Bandung; Al-Ma'arif.

Beuchamp,G.A., (1968). Curriculum Theory, Wilmete: The Kagg Press.

Langgulung, Hasan., (1988). Asas-asas Pendidikan Islam, Jakarta: Pustaka AlHusna.

Langgulung, Hasan., (1986). Manusia dan Pendidikan: Suatu Analisa Psikologi dan Pendidikan, Jakarta: Pustaka Al-Husna.

Qurah, Husayn Sulaiman., (1975). Al-Ushul al-Tarbawiyyah fi Bina' al-Manahij, Cairo: Dar al-Ma'arif.

Barnadib, Imam., (1996). Filsafat Pendidikan, Jogjakarta: Andi Offset.

Jalaluddin dan Umar Said., (1996). Filsafat Pendidikan Islam: Konsep dan Perbandingan Pemikirannya, Jakarta: raja Grafindo Persada.

Rosyadi, Khoiron., (2004). Pendidikan Profetik, Yogyakarta: Pustaka Pelajar. Hadjar, Ibnu,1993. "Pendekatan Holistik dalam Pendidikan Islam (Sebuah Upaya untuk Efektifitas Pelaksanaan Kurikulum)", dalam Ismail SM dkk. (ed.), Paradigma Pendidikan Islam, (Yogyakarta: Pustaka Pelajar, 2001), h. 124. Bandingkan dengan Muhaimin, Konsep Pendidikan Islam: Telaah Komponen dasar Kurikulum, Solo: Ramadhani.

Nurkancana, Yuyun\& PPN Sumantara., (1986). Evaluasi Pendidikan, Surabaya: Usaha Nasional. 
Arikunto, Suharsimi., (1991). Dasar-dasar Evaluasi Pendidikan, Jakarta: Bumi Aksara.

Purwanto, M. Ngalim., (1992). Prinsip dan Teknik-teknik Evaluasi Pengajaran, Bandung: Remaja Rosdakarya.

M. Arifin., (1993). Filsafat Pendidikan Islam, Jakarta; Bumi Aksara.

Rahardjo, M. Dawam., (1989). Insan Kamil, Jakarta: Pustaka Firdaus.

Shihab, M. Quraish., (1992). Membumikan Al-Qur'an: Fungsi dan Peran Wabyu dalam Kebidupan Masyarakat, Bandung: Mizan.

Al-Abrasyi,Muhammad Athiyah., (1974). Dasar-dasar Pokok Pendidikan Islam, Jakarta: Bulan Bintang.

Al-Baqy, Muhammad Fu'ad 'Abd., (1987). al-Mu'jam al-Mufabras li Alfadz alQur'ân, Bairut: Darul Fikr.

Haikal, Muhammad Husain., (1992). Sejarah Hidup Muhammad, terj. Ali Audah, Jakarta: Litera Antar Nusa.

Qutb, Muhammad., (1984). Sistem Pendidikan Islam, Bandung: Remaja Rosda Karya.

Arifin, Muzayyin., (1994). Ilmu Pendidikan Islam, Suatu Tinjauan Teoritis dan Praktis Berdasarkan Pendekatan Interdisipliner, Jakarta: Bumi Aksara.

As-Syaibany, Omar Mohammad al-Toumy., (1979). Falsafah Pendidikan Islam, terj. Hasan Langgulung, Jakarta: Bulan Bintang,

Pidato Sikun Pribadi dalam Kongres Ilmu Pengetahuan II dengan judul "Psycho Higiene" dalam In Search of Formulation of General Education Aim of Education, Vol. IV, Bandung: LPPD IKIP Bandung, 1971.

Sabiq, Sayyid Sabiq., (1977). Aqidah dan Pola Hidup Manusia Beriman, terj. M. Abdai Rathomy, Bandung: CV. Diponegoro. 